\title{
Taxonomy and phytoecology of palynomorphs and non-pollen palynomorphs: a refined compendium from the West Africa Margin
}

\begin{abstract}
Late Quaternary low latitude tropical pollen study often pose difficulties during microscopic identifications due to their high diversification and complex nature. This compendium is an illustrated guide to the identification of sporomorphs (pollen and spores) and nonpollen palynomorphs (NPPs) preserved and recovered from 3 gravity cores (GCs) in deltaic-sedimentary records of the Niger Delta, West Africa. The precise and reliable identification of palynomorphs and non-pollen palynomorphs (NPPs) is indispensable to permit comprehensive deduction to be made regarding past environmental change, phytoecological and biogeographical distributions of fossil pollen and NPPs.
\end{abstract}

Keywords: late quaternary, taxonomy; phytoecology, biogeography, angiosperm pollen, pteridophyte spores, Niger delta
Volume 3 Issue 5 - 2019

\author{
Onema Adojoh, 1,2 Marret Fabienne,' Robert \\ Duller,' Peter Osterloff ${ }^{3}$ \\ 'School of Environmental Sciences, University of Liverpool, UK \\ ${ }^{2}$ Geosciences and Geological and Petroleum Engineering, \\ University of Missouri Science and Technology, USA \\ ${ }^{3}$ Exploration and Production, Shell International, UK
}

Correspondence: Onema Adojoh, School of Environmental Sciences, University of Liverpool, L69 7ZT, UK, Email adojoho@mst.edu

Received: June 16, 2019 | Published: September 20, 2019

\section{Introduction}

Due to the high diversification and complex nature of low latitude tropical pollen research in palynology and palaeobotany, most researchers are often faced with difficulties in taxonomic identification and grouping of species into their family affinity. This identification and grouping are necessary in order to reflect the vegetational and ecological dynamics rather than assuming a species entity based on their morphology alone. This study present a hamonised taxonimic and photomontage update of sphoromorphs and non-pollen palynomorphs (NPPs) in relation to their phytoecology, biogeography and family/ botanical affinities from the Niger Delta (Figure 1). The monotonous taxonomy, phytoecology, biogeography and family/botanical affinities complexities of species has been existing since its commencement. This practice is through evaluation and comparison of morphological description and identification of sporomorphs (pollen and spores) and NPPs with modern material. Later, several compendia for pollen, spores and NPP identification have been documented from different region worldwide. ${ }^{2-6}$ The reliability of the information provided by palaeobotanists and palynologists to the study of palynomorph and NPPs is dependent on accurate visualisation or, where possible, identification and confirmation of the strewn mount assessed from the processed slides.

Given the tedious taxonomic nature associated to low latitude tropical palynomorphs and non palymorphs, few reputable substantial atlases for African pollen, spores and NPPs identification were produced over the years. ${ }^{7-20}$

Here, this study produces a compendium of taxonomic and photomicrographsupdate with the combinination of phytoecology, biogeography and family/botanical affinities of palynomorph and NPPs from the Niger Delta. The aim is to avoid any potential wrong assignment of identified pollen to inappropriate ecology or vegetational group. For instance, this study is about the first in West Africa to separate Pteridophytes Trilete and Pteridophytes-Monolete Spores, in addition to the previous studies in the region. ${ }^{14,21}$ In essence the pollen, spores and NPPs were first identified, described in line with correct morphological parameters to allow assignment with correct family or botanical affinity. ${ }^{20,22}$ Before linking their description to their phytoecology and biogeography through time. Thus, in alignment with the International Palynological Congress ${ }^{23}$ and others updates, this study adopted both the morphological and botanical (family) identification to make a concise clarification that different taxa in the same family may occur in more than one vegetation group/ sub-group. ${ }^{4,22,24}$ Sporomorphs grouped into family/botanical affinity would reduce the potential ambiguity arising from the industrial and academic understanding of different species concepts and origins due to their extensive diversity and complexity as stated above. Finally, the statistical computation of the vegetation, climate and environmental dynamics aspects of this study are already published. ${ }^{24}$

\section{Methods, materials and nomenclature}

The identification of palynomorph and NPPs nomenclatures / phyecological analyses undertaken in this study are based primarily on the previous. ${ }^{25-30}$ The identification of taxa is by the examination of the grains, shape, size, wall structure, arrangement of the pores and colpi (morphological characteristics). ${ }^{20,28}$ These were achieved by routine description of most key taxa identified. Most importantly, this study considered the grouping of each species identified under their phytoecology, family/botanical affinity and biogeographical distribution as a guide for interpretation of the palynomorphs records for future studies. ${ }^{24}$ Generally, the generic nomenclature for the foraminifera test lining, fungal spores and palynodebris (NPPs) follows. ${ }^{31,32}$ No detailed description was made of their identification, whereby such identification has been achieved using technical expertise of known specialists, and comparative data through photographs. The 
plate galleries of the identified pollen, spore and NPPs morphology are organised to allow ease reference and comparison of the species photos description of all pollen and spores (Plates 1-5). In addition, an annotated table with references and species names was provided as well. Given key introduction, the sections below describes the various palynomorphs (e.g., angiosperm, gymnosperm, bryospores and NPPs see Plates 1-5) identified from the gravity cores based on their morphological characteristics. Three groups of palynomorph descriptions and identifications were compiled according to the microphotography from the slides. These includes: pollen, spores and NPPs.

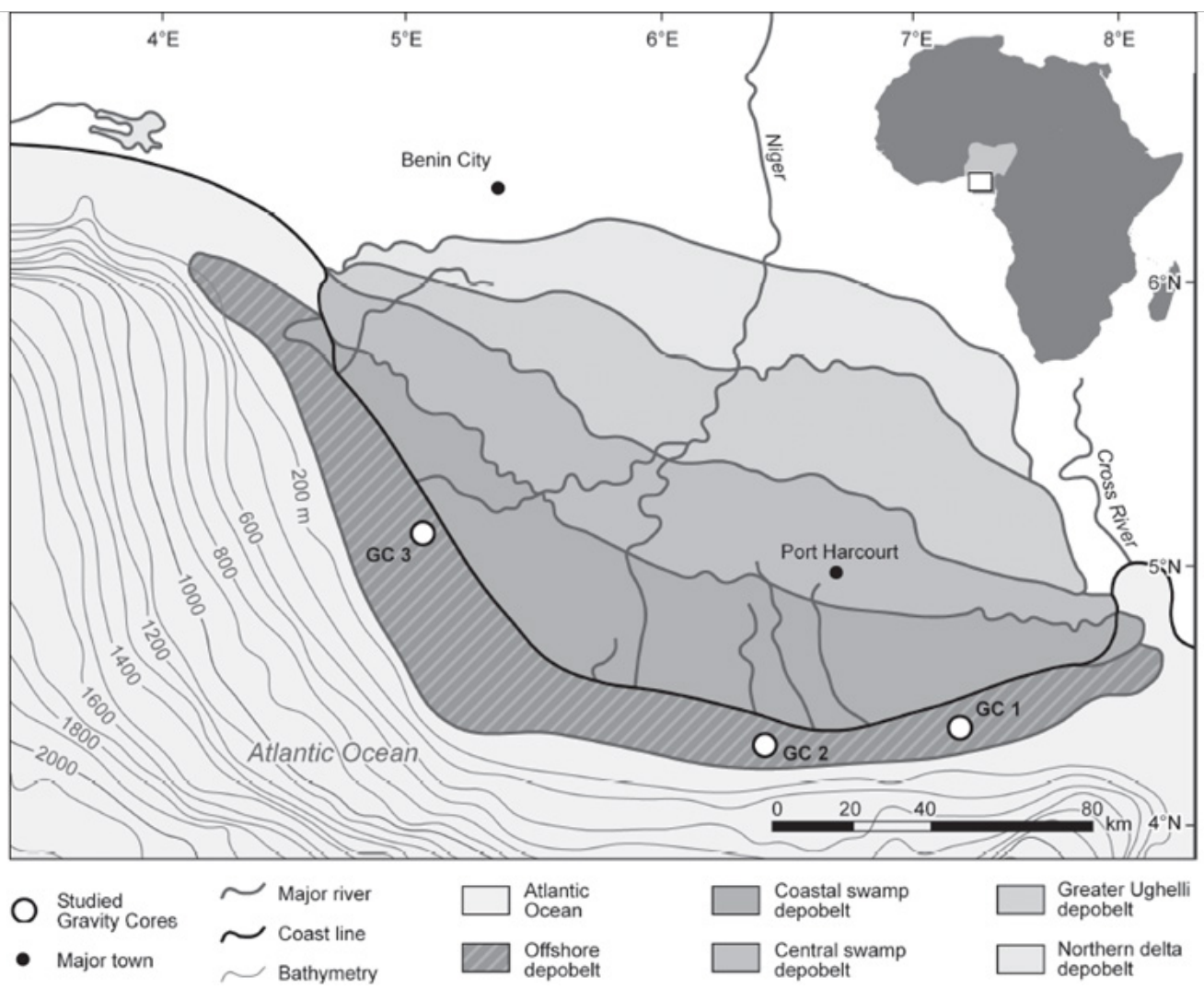

Figure I Location of the Niger Delta and gravity cores positions (GCs).24,26

A) Angiosperm pollen

Plate 1
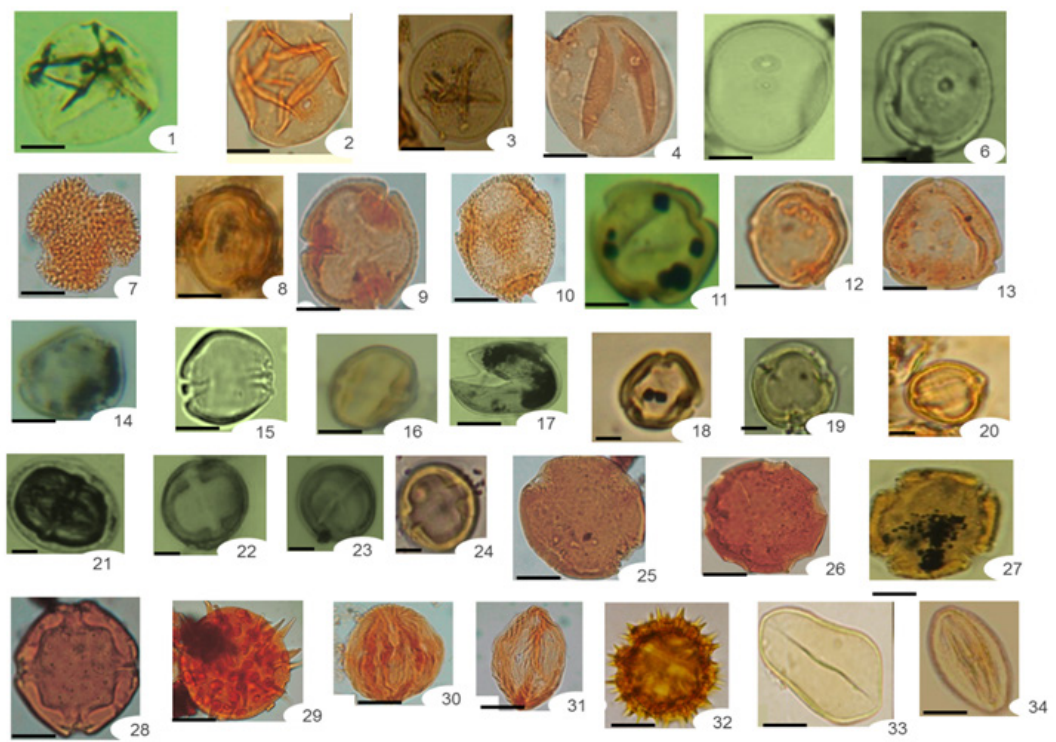

Plate I (A) Angiosprem pollen. 
A) Angiosperm pollen
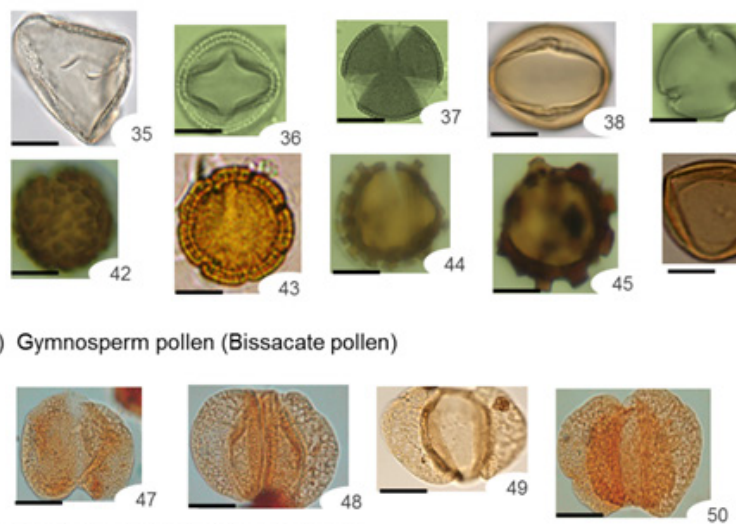

C) Pteridoph i) Trilete spores
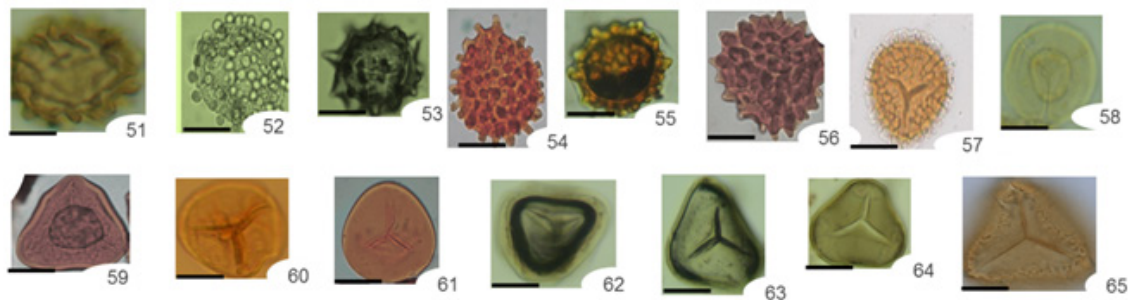

Plate 2 (A) Angiosprem pollen, (B) Gymnosperm Pollen, (C) Pteriodophyte and bryophyte spores.
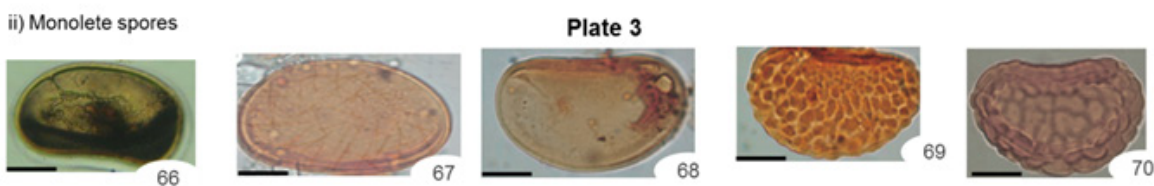

D) Non Pollen Palynomorphs (NPPs)

i) Foraminifera Test Lining (FTL)
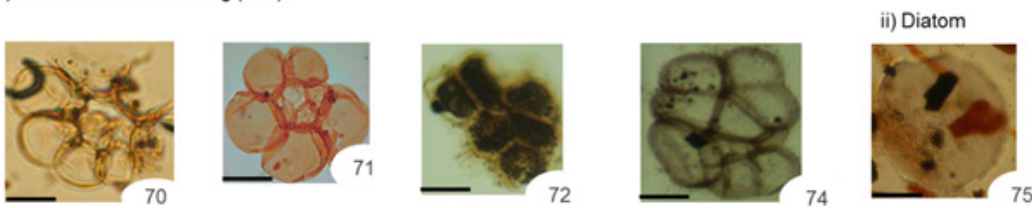

iii) Fresh / brackish water algae
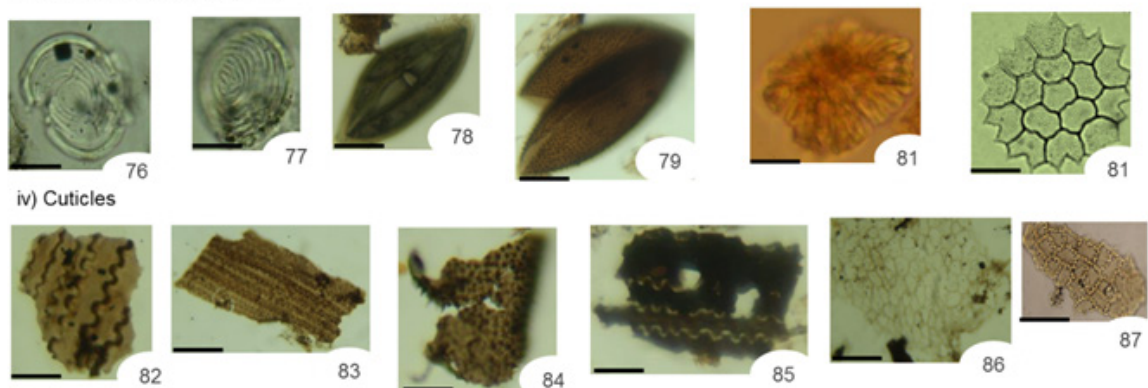

Plate 3 (D) Non pollen Palynomorphs. 


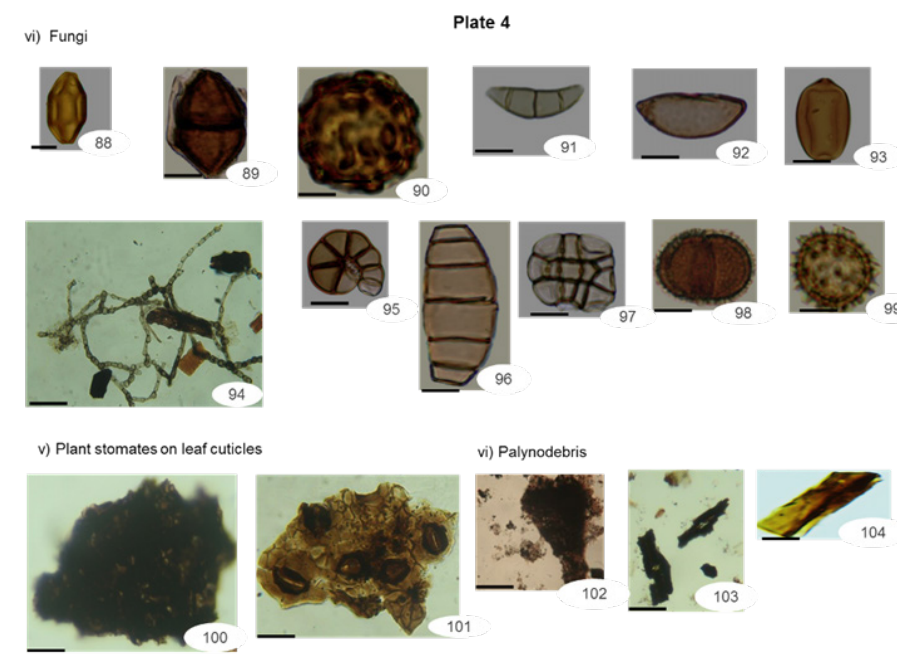

Plate 4 Fungi, Plant stomates on leaf cuticles.

\section{Pollen}

\section{Angiosperm pollen}

\section{Monoporate pollen types}

Family/botanical affinity: Poaceae Plate 1, Figures 1-6.

Description and remarks: Monoporate pollen grains are often referred to as pore pollen. This is because the most pronounced descriptive feature is the pore. The pore is rounded with the distinct granulate annulus $(5 \mu \mathrm{m})$. The exine is smooth and circular in shape which in size ranges between 20 and $25 \mu \mathrm{m}$ in most cases. These are ubiquitous pollen that evolved throughout the Quaternary in Africa belongs to the family Poaceae (Gramineae). In addition, it has a uniform morphology and possesses one distinct annulate pore. ${ }^{11,34}$

Morphogenic affinity: Graminidites annulatus (Monoporites annulatus), Phytoecology: Savannah grassland

\section{Tricolporate pollen types}

Family/Botanical Affinity: Tabermaemontana / Apocynaceae; Plate 1, (Figures 8\&9).

Description and remarks: The outline in polar view is rounded triangular with endexine $2 \mu \mathrm{m}$ thick. The tectum psilate is finely perforate, about $1.5 \mu \mathrm{m}$ thick with the colpus 25 to $30 \mu \mathrm{m}$ long (tapering very sharp towards the costate of about $4.5 \mu \mathrm{m}$ ). The biogeographical references show that they are ubiquitous pollen within the Quaternary time frame, and mostly common in Nigeria, Cameroon and Venezuela regions. ${ }^{11,24,36}$

Morphogenic affinity: Psilatricolporites crassus, Phytoecology: Mangrove swamp vegetation.

Family/Botanical Affinity: Euphorbiaceae/Alchornea; Plate 1, Figure 15.

Description and remarks:This type is similar to Psilatricolporites crassus except that it has a distinct operculum of about $2-2.5 \mu \mathrm{m}$. The entire size is elongated at the equator, and with a finely perforated exine of Alchornea cordifolia $\sim 2.5 \mu \mathrm{m}$ thick. This range in size

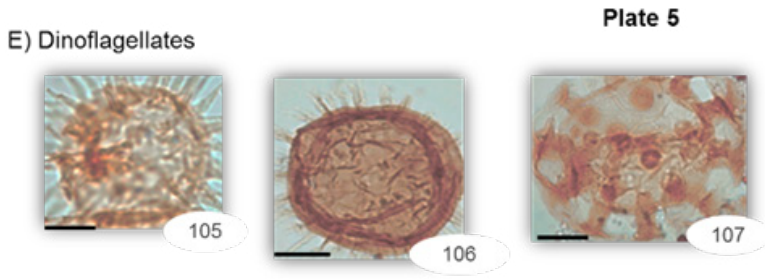

Plate 5 Dinoflagellates.

between 25 to $30 \mu \mathrm{m}$. The species occurs throughout the Cenozoic to Quaternary.

Morphogenic affinity: Psilatricolporites operculatus, Phytoecology: Lowland rainforest

Family/Botanical Affinity: Euphorbiaceae/Amanoa; Plate 1, Figure 7.

Description and remarks: The species is a tricolporate pollen in a circular polar view with psilate sculpture. The colpus is $2 \mu \mathrm{m}$ thick and pointing towards the end of the costae. However, the endexine is less than $1 \mu \mathrm{m}$ and bacules are about $1.5 \mu \mathrm{m}$ thick, supporting single rows of curvimurate reticulum. The lumina is quite irregular in shape and are up to $6 \mu \mathrm{m}$ in length. The size of Amanoa oblongifolia is between 32 to $33 \mu \mathrm{m}$ in the GCs samples. In general, the taxon evolved through the Eocene to Recent in Nigeria and Venezuela. ${ }^{11,24,36}$

Morphogenic affinity: Retitricolpites irregularis, Phytoecology: Lowland rainforest.

Family/Botanical Affinity: Euphorbiaceae?; Plate 1, Figures $11,13 \& 14$.

Description and remarks: The exine is thicker than $2.3 \mu \mathrm{m}$ as observed from other Euphorbiaceae mentioned above. The size is between $25-30 \mu \mathrm{m}$ with the shape is oval to broad-ellipsoidal or prolate. Most of the Euphorbiacea family common in Nigeria range from the mid-Cenozoic to Quaternary. ${ }^{37}$

Morphogenic affinity: Momipites africanus, Phytoecology: Lowland rain forest

Family/botanical Affinity: Cannabaceae/Celtis; Plate 1, Figure 12.

Description and remarks: The exine is thicker, about $2.4 \mu \mathrm{m}$ with size ranging between $23-32 \mu \mathrm{m}$. The shape is slightly oval to broad ellipsoidal as common in the species from Nigeria which evolved in the mid-Cenozoic onwards. ${ }^{24,37}$

Morphogenic affinity: Triporites? Phytoecology: Lowland rain forest/Open forest 
Family/Botanical Affinity: Rhizophoraceae/Rhizophora; Plate 1, Figures 18-24.

Description and remarks: The pollen grain has a circular to rounded triangular shape in polar view. The sculpture is punctate to micro-reticulate with the dimension of the pollen is $1.7-2.0 \mu \mathrm{m}$. The tiny perforation (hole) observed is less than $0.5 \mu \mathrm{m}$ in width and the exine is less than $2.0 \mu \mathrm{m}$ thick for most specimen. The specimens display a variety textures ranging from size and texture (coarseness) of the subtypes identified. These were grouped as Rhizophora because the similar taxonomy make it easy to use their gross morphology to define the palaeoecology and palaeoenvironmental change. Among species identified are Rhizophora racemosa, Rhizophora mucronata and Rhizophora mangle. The few Rhizophora identified evolved through the Cenozoic onward in Nigeria, Venezuela, Cameroon and Borneo. ${ }^{11,25,36-40}$

Morphogenic affinity: Zonocostites ramonae, Phytoecology: Mangrove swamp vegetation.

Some types of tricolporate pollen that were not identified in this study are due to lack of morphological clarity on the observed pollen. The following are some pollen types:

Morphological Affinity: ?Tricolporate sp. : Plate 1, Figure 34.

Family/Botanical Affinity: Asteraceae/Vernonia-type; fenestrate; Plate 1, Figure 32.

\section{Morphological Affinity: Tricolporate sp.} 56.

Family/Botanical Affinity: Asteraceae/Tubliflorae; Plate 2, Figure

\section{Morphological Affinity: Tricolporate echinate}

Family/Botanical Affinity: Avicenniaceae/Avicennia; Plate 1, Figures 36\&37.

Description and remarks: The pollen grains are monads of medium size ranging from oblate spheroidal to subprolate, isopolar, circular amb; 3-colporoidate (more common), and 3-colporate to 3 -colpate. The sizes for the observed specimens range between 31 to $33 \mu \mathrm{m}$. The dimension is $2 \mu \mathrm{m}$ wide with ectoaperture and elongate endoaperture, narrow in the first and wide in the second type. The exine is heterobrochate with interrupted muri, and thick in the mesocolpium. This specimen has been observed to evolve from the Eocene to Recent in some parts of Nigeria, Borneo, Indonesia, and Venezuela. ${ }^{11,24,36}$ swamp

Morphogenic affinity: Avicennia spp., Phytoeoecology: Mangrove

Family/Botanical Affinity: Fabaceae/Chamaecrista; Plate 1, Figures 38-40.

Description and remarks: The pollen grains are of small size between 5 to $10 \mu \mathrm{m}$. Other pollen grains attribute are isopolar features, radial symmetry, subprolate shape, amb subcircular slightly sinuaperturate, 3-colporate, longiaperturate, colpi with pointed apices, psilate margo- with central constriction, and slightly thicker sexine than the nexine. Studies shows that this is well-known to evolve during Eocene to Recent in some parts of Nigeria, Cameroun, Benin Republic, Brazilian Amazon. ${ }^{24,41}$

Morphogenic affinity: Chamaecrista spp., Phytoecology: Mangrove swamp vegetation

Tricolpate pollen types
Family/Botanical Affinity: Caesalpiniodeae/Anthonotha, Berliniatype; Plate 1, Figures 30\&31.

Description and remarks: These are tricolpate pollen with a prolate shape. The proximal view is striated with one to several rows of bacules and lirae. The exine is finely striated and overall size is between 30 to $36 \mu \mathrm{m}$ on the equatorial view. This has been noted to evolve during the Eocene to Recent in some parts of Nigeria, Borneo and Cameroon. ${ }^{11,24,37}$

Morphogenic affinity: Striatocolpites spp., Phytoeoecology: Lowland rainforest

\section{Stephancolpate pollen types}

Family/Botanical affinity: Rubiaceae/Spermacoce (Borreria sp.) Plate 2, Figures 43-45.

Description and remarks: These are polycolpate pollen grain with a circular polar view. Exine of numerous tectate-baculae are distinctly stratified and sculptured. Grains observed range in size between 38 to $41 \mu \mathrm{m}$ for the identified species. The exine is about $4-5 \mu \mathrm{m}$ in thickness and stout baculae are $3-5 \mu \mathrm{m}$ long and $0.7 \mu \mathrm{m}$ thick. It evolved through the late Miocene to Recent sediment in some parts of Nigeria and Cameroon. ${ }^{24,42-44}$

Morphogenic affinity: Stephanocolpites sp., Phytoeoecology: Lowland rain forest

Polyporate pollen types

Family/Botanical Affinity: Clusiaceae/Symphonis globulifera, Plate 1, Figures 26-28.

Description and remarks: It consists of tetrapororoidate to tetrapororate pollen grain with four to six apertures in most cases. Their sizes (diameter) are $42-44 \mu \mathrm{m}$ with the ecto-enxinous pore between $6-7.5 \mu \mathrm{m}$ in length/thickness. The endexious pore are characteristically demarcated for most taxa identified. The exine is finely vermiculate to punctate with a smooth and comparatively thin tectum for tetraporate pollen identified. The endexine is very thick and perforated at the apertures for all forms identified in this study. It mostly evolves through Eocene to Recent in Nigeria, Cameroon, Venezuela. ${ }^{11,12,24,25,36,42}$

Morphogenic affinity: Pachydermites diederixi, Phytoeoecology: Fresh water swamp/Lowland rain forest 29.

Family/Botanical Affinity: Malvaceae/Hibiscus, Plate 1, Figure

Description and remarks: This morphotype is a polyporate pollen grain with oval or circular outline. The size is $30-45 \mu \mathrm{m}$ with spines between $5-6 \mu \mathrm{m}$ long and pores between $3-4 \mu \mathrm{m}$ wide. The coarseness of the wall structure and spines varies depending on the species. This type of species evolved through the Eocene to Recent in Nigeria and Cameroon. ${ }^{11,42,36,45}$

Morphogenic affinity: Echiperiporites estelae., Phytoeoecology: Open forest

Family/Botanical Affinity: cf. Ipomoea/Convolulaceae, Plate 2, Figure 41.

This polyporate pollen was not described due to unavoidable ubiquity observed during identification.

Phytoeoecology: Mangrove swamp

Family/Botanical Affinity: Palmae/Arecaceae, Plate 1, Figure 33. 
Description and remarks: There is not much literature to cover for this morpho-type, as suggested. ${ }^{44}$ Most of the information reviewed are documented in "grey literature". This is because of the proprietary issues associated with acquiring company data. However, an attempt to the look at the colpi relationships along with other descriptions has been taken into consideration. The generic size of Arecaceae is 58 to
$60 \mu \mathrm{m}$ with a mono colpi which is $15-20 \mu \mathrm{m}$ long. The morpho-group is known to have evolved during the Eocene to Recent in Nigeria and Cameroon. ${ }^{44,46,24}$

Morphogenic affinity: Psilamonocolpites sp., Phytoeoecology: Palmae, fresh water swamp/riverine. Table $1 \&$ Plate 1.

Table I (A) Angiosperm pollen

\begin{tabular}{|c|c|c|c|}
\hline \multicolumn{4}{|c|}{ Angiosperm Pollen (A) } \\
\hline Figure & Family name & Morphological name & References \\
\hline $\mathrm{I}-6$ & Poaceae & Graminidites annulatus & van der Hammen, ${ }^{33}$ Potonié ${ }^{81}$ \\
\hline 7 & Euphorbiaceae & Retitricolporites irregularis & van der Hammen ${ }^{35}$ \\
\hline 8,9 & Apocynaceae & Psilatricolporites crassus & $\mathrm{Sah}^{52}$ \\
\hline 10 & Euphorbiaceae/Rubiaceae & Retibrevitricolporites obodoensis & Legoux,, ${ }^{12}$ Germeraad et al.," \\
\hline $11,13,14$ & Euphorbiaceae & Momipites africanus & van Hoeken-Klinkenberg, ${ }^{47}$ \\
\hline 12 & Cannabaceae & Celtis & Legoux, ${ }^{12}$ \\
\hline 15 & Euphorbiaceae/ Alchornae & Psilatricolporites operculatus & van der Hammen ${ }^{35}$ \\
\hline 16 & Rhizophoraceae & Rhizophora sp. & Germeraad et al.," \\
\hline 17 & & Inaperturotetradites reticulatus & Salard-Cheboldaeff, ${ }^{44}$ \\
\hline $18-24$ & Rhizophoraceae & Rhizophora spp. & Germeraad et al.," \\
\hline $25-28$ & Clusiaceae & Pachydermites diederixi & Germeraad et al.," \\
\hline 29 & Malvaceae & Echiperiporites estelae & Germeraad et al.," \\
\hline $30-31$ & Arecaceae/Anthonotha & Striatocolpites spp. & González Guzmán, ${ }^{77}$ Takahashi ${ }^{37}$ \\
\hline 32 & Asteraceae & Vernonia-type & Erdtman, ${ }^{75}$ Adekanmbi, ${ }^{70}$ \\
\hline $33-34$ & Arecaceae & Psilamonocolpites sp. & van der Hammen ${ }^{33}$ \\
\hline
\end{tabular}

\section{Gymnosperm pollen}

Family/Botanical Affinity: Podocarpaceae/ Podocarpus, Plate 2, Figures 47-50.

Description and remarks: They are bisaccate pollen with the sacci firmly attached to the body. This is usually rounded with different sacci sizes. They are bisaccate pollen with the saccates wide open in most species. The exines are thin and finely granulated. Their sacci are coarsely grained with size ranging between 25 to $30 \mu \mathrm{m}$. The sacci are between 10 to $15 \mu \mathrm{m}$ for the types identified. They evolve through mid-Miocene to Recent in Burundi, Cameroun, Nigeria, and Southern Hemisphere. ${ }^{11,36,44}$

Morphogenic affinity: Podocarpus clarus, Podocarpus sp., Phytoeoecology: Afromontane vegetation.

Nonangiosperm and gymnosperm groups are described below

Family/Botanical Affinity: Nymphaceae/Nymphaea type lotus, Plate 1, Figure 46.

Description and remarks: It is a zonosulcate pollen characterised by a circular to elliptical outline. The size of the pollen ranges from 38 to $53 \mu \mathrm{m}$. The sulcus is conspicuously broad and covers most of the pollen grain. Nymphaceae has a partly smooth and psilate exine. Nymphaceae evolves through the late Miocene to recent sediments in most West African settings and Europe. ${ }^{47}$

Morphogenic affinity: Psilamonoporites sp., Phytoeoecology: Fresh water swamp

Family/Botanical Affinity: Cyperaceae, Plate 1, Figure 35.

Description and remarks: It is an elongated angiosperm pollen grain with granulate apertures. The size is about 19 to $22 \mu \mathrm{m}$. The overall morphology flattens as spheroidal, narrowing towards the dorsal view. It is recorded through the Miocene to recent sediments in Nigeria and Ghana. ${ }^{20,24,48}$

Morphogenic affinity: Cyperus sp., Phytoeoecology: Fresh water swamp

Family/Botanical Affinity: Arecaceae/ Borassus type; Plate 2, Figure 52, Table 2. 
Table 2 (A) Angiosperm pollen, (B) Gymnosperm pollen, (C) Pteriodophyte and bryophyte spores

\begin{tabular}{|c|c|c|c|}
\hline Figure & Family name & Morphological name & References \\
\hline 35 & Cyperaceae & Cyperus sp. & Germeraad et al.," \\
\hline $36-37$ & Avicenniaceae & Avicennia sp./ Foveotricolpites spp. & Rull, $^{63}$ \\
\hline $38-40$ & Fabaceae & Chamaecrista spp. & Miller eta l.,20 \\
\hline 41 & Convolvulaceae/cf Ipomoea & Echiperiporites sp. & University of Arizona Herbarium ${ }^{86}$ \\
\hline $43-45$ & Rubiaceae/ Spermacoce (Borreria) & Stephanocolpites sp. & Regali et al. ${ }^{42}$ \\
\hline 46 & Nymphaceae & Nymphaea lotus type/ & Saad et al., ${ }^{84}$ Miller et al. ${ }^{20}$ \\
\hline \multicolumn{4}{|c|}{ Gymnosperm Pollen / Bisaccate Pollen (B) } \\
\hline $47-50$ & Podocarpaceae & Podocarpidites sp. & Germeraad et al.," \\
\hline 49 & Podocarpaceae & Podocarpidites clarus & $\mathrm{Sah}^{, 52}$ \\
\hline \multicolumn{4}{|c|}{ (III \& IV) Pteridophyte and Bryophyte spores (C) } \\
\hline $5 I-56$ & Asteraceae & Tubliflorae sp. & Krutzsch $^{50}$ \\
\hline 52 & Arecaceae & Borassus type & \\
\hline 57 & Lycopodiaceae & Lycopodiumsporites sp. & Sowunmi, ${ }^{66}$ \\
\hline $58-59$ & Polypodiaceae & Undulatisporites sp. & Delcourt et al., ${ }^{73}$ Krutzsch $^{50}$ \\
\hline 60 & Bryophyta & Stereisporites sp. & Salard-Cheboldaef et al. ${ }^{45}$ \\
\hline $62-64$ & Polypodiaceae & Polypodiaceoisporites sp. & $\mathrm{Sah}^{, 52}$ \\
\hline 65 & Pteridaceae/Acrostichum & Acrostichumsporites sp. & $\mathrm{Kar}^{55}$ \\
\hline
\end{tabular}

\section{Spores}

This group comprises of fern spores such as Lycopodium sp., Polypodiaceoisporites sp., Acrostichum sp., Corrusporis sp. All spores belonging to these group were separated in this study into the following types - alete, monolete and trilete spores.

Pteridophytes-monolete spores

Family/Botanical Affinity: Pteridophyta; Plate 3, Figures 66-68.

Description and remarks: These are monolete spores with size ranging from 15 to $25 \mu \mathrm{m}$ in length/diameter. These spores are similar in shape to kidney beans. The monolete mark ranges in length from 6 to $8 \mu \mathrm{m}$ for the species identified. The length of Polypodiaceae spores ranges from 45 to $64 \mu \mathrm{m}$ for most species observed. It evolved through Eocene to recent sediments. It has been documented to have been found in Indonesia, Nigeria, East Europe, East China Sea and Colombia. ${ }^{24,37,49,50}$

Morphogenic affinity: Laevigatosporites spp., Phytoeoecology: Lowland rain forest/open forest.

Family/Botanical Affinity: Polypodiaceae, Plate 3, Figures 69\&70.

Description and remarks: These are monolete spores with elliptical shape outline in polar view. It is of similar shape to the laevigate spores described above in equatorial view. It has a verrucate exine sculpture with size ranging from 35 to $48 \mu \mathrm{m}$ for the species identified. The exine sculpture is coarsely and closely spaced (diameter $2.5 \mu \mathrm{m}$ ). The current taxonomic nomenclature documents that this species should be renamed as Polypodiaceoisporites sp. However, some other authors still refer to it as Verrucatosporites usmensis. It is a ubiquitous pollen that evolved through the Eocene to Recent in Nigeria, Western Europe (Germany) and Borneo. ${ }^{11,24,42,52}$

Morphogenic affinity: Polypodiaceoisporites sp. (aka Verrucatosporites usmensis)., Phytoeoecology: Lowland rain forest/
Open forest

Pteridophytes -trilete spores

Family/Botanical Affinity: Pteridophyta/fern spores? Plate 2, Figures 58\&59.

Description and remarks: These are trilete spores similar to Polypodiaceosporites sp. It has a thicker exine width size which ranges from 34 to $35 \mu \mathrm{m}$. It has smooth exine about $1.6 \mu \mathrm{m}$ thick. It is very common in Germany during the Pliocene. ${ }^{50,53}$ They are known to occur between the Eocene and Recent in Nigeria. ${ }^{14,24}$

Morphogenic affinity: Undulatisporites sp., Phytoeoecology: Lowland rain forest/Open forest

Family/Botanical Affinity: Pteridaceae/Acrostichum; Plate 2, Figure 65.

Description and remarks: A trilete spore with distinct spherical or ellipsoidal shape in some specimens. The exine is irregular fairly covered verrucate features. The size of Polypodiaceae spores ranges from 62 to $67 \mu \mathrm{m}$ in most of the specimens measured. The length of the trilete mark is $3 \mu \mathrm{m}$ for either side. It evolved throughout the Miocene to Recent in very few African countries like Cameroun, Congo and some North African countries. ${ }^{54,55}$ This species is recorded in modern and ancient sediments in NW Borneo. It lives behind the brackish water mangrove vegetation, where fresh water collects in the middle of mangrove islands, with slightly raised elevations, and above high water mean level (Osterloff, pers. comm.).

Phytoeoecology: Mangrove swamp vegetation, Morphogenic affinity: Acrostichumsporites sp.

Family/Botanical Affinity: Polypodiaceae, Plate 2, Figures 62-64.

Description and remarks: They are sub-circular to triangular shaped in distal and proximal view. The size of Polypodiaceae ranges 
from 30 to $32 \mu \mathrm{m}$. The trilete mark is $4 \mu \mathrm{m}$ when critically viewed. The exine is about $1.6 \mu \mathrm{m}$ in thickness/length. Evolved throughout the Early Miocene to Recent in Germany, in a few African countries like Cameroon, Congo and some North African countries (e.g. Tunisia, Morocco). ${ }^{24,50,52,56}$

Morphogenic affinity: Polypodiaceoisporites sp., Phytoeoecology: Lowland rainforest

Family/Botanical Affinity: Lycopodiaceae, Plate 2, Figure 57.

Description and remarks: This is a trilete spore with a triangular outline view. The side of the trilete spore is slightly concave in polar view. The exine is smooth and heaving-like in the overall thickness. The size of the equatorial diameter ranges between 25 to $26 \mu \mathrm{m}$. The trilete or laesurae arms are almost bifurcating at the radius of entire dimension. It evolves through the Late Oligocene to Recent sediment in some parts of Nigeria, Benin and Cameroon..$^{24,42,57}$
Morphogenic affinity: Lycopodium sp., Phytoeoecology: Lowland rain forest.

Bryophyte spores

Family/Botanical Affinity: Bryophyta; Plate 2, Figure 60.

Description and remarks: It is usually triangular to sub-triangular in polar view. The laesurae arms are $5 \mu \mathrm{m}$ long and nearly tamper at the equator. The margin of the laesurae arms is slightly thickened, but less than $1 \mu \mathrm{m}$. The size of the laesurae is between 25 to $35 \mu \mathrm{m}$. Most of the species viewed have a psilate exine of about $2 \mu \mathrm{m}$. It mostly evolves throughout the Oligocene to Recent in some parts of Europe, Nigeria, North West Poland and Cameroon. ${ }^{24,44,53}$

Morphogenic affinity: Stereisporites sp., Phytoeoecology: Lowland rain forest/ Open forest, Plate 3 \& Table 3.

Table 3 (D) Non pollen Palynomorphs

\begin{tabular}{llll}
\hline Figure & Family name & Morphological name & References \\
\hline $66-68$ & Pteridophyta & Laevigatosporites spp. & Potonié ${ }^{81}$ \\
69,70 & Polypodiaceae & Polypodiisporites sp./Verrucatosporites usmensis & van der Hammen, ${ }^{33}$ Rull $^{13}$ \\
Non-Pollen & Palynomorphs (NPPs) & (D) & \\
71,72 & Foraminifera & Planospiral FTL & Tyson ${ }^{32}$ \\
73,74 & Foraminifera & Biserial/Triserial FTL & Tyson $^{32}$ \\
75 & Diatom & Diatom & - \\
76,77 & Fresh water algae & Pseudoschizea sp. & Thiergart et al. ${ }^{65}$ \\
78,79 & Zygnemataceae & Ovoidites parvus & Thiergart et al. ${ }^{65}$ \\
80 & Brackish water algae & Botryococcus sp. & Batten et al..${ }^{64}$ \\
81 & Fresh water algae & Pediastrum sp. & Gelorini et al. ${ }^{8}$ \\
$82-85$ & Graminae & Grass cuticles & Morley et al. ${ }^{39}$ \\
86,87 & Plantae & Plant cells & Tyson ${ }^{32}$ \\
\hline
\end{tabular}

\section{Non-pollen palynomorphs (NPPs)}

These are microfossils other than pollen and spores from plants. They include micropscopic remains of algae, cyanobacteria, fungi, palynodebris, phytoplankton (dinoflatgelletes), etc. There are no detailed descriptions on the identified specimens in this study as detailed identifications has been done in recent studies. ${ }^{14}$ Below are some of the groups identified :

\section{Dinoflagellate cysts}

Polysphaeridium sp. Plate 5, Figure 105.

It evolves through the Paleogene in Colombia and Miocene to Recent in West Africa. ${ }^{58,59}$ The observed size ranges between 34.1 to $47 \mu \mathrm{m}$.

\section{Lingulodinium sp. Plate 5, Figure 106.}

The biogeographical references indicate that it evolves through Oligocene to Pleistocene sediments as described by many authors in different parts of the world. ${ }^{60}$ Most of the species identified ranges between 61.4 to $65 \mu \mathrm{m}$ in size.
Tuberculodinium vancampoae, Plate 5, Figure 107.

This is a typical neritic species which evolves through the Pliocene to Recent sediment. ${ }^{60}$ The size identified in this study is about $96 \mu \mathrm{m}$ depending on the view.

\section{Foraminiferal Test Linings (FTLs) ${ }^{61}$}

The microforaminiferal lining consist of the inner organic layer that lies between the cytoplasm and the internal surface of the test of several foraminifera such as calcareous and agglutinated. ${ }^{61}$ In this study, few were identified from the samples (Plate 3, Figures 70-75).

\section{Algae}

These are unicellular or multicellular organisms formerly classified as plants, occurring in fresh or salt water or moist ground, that have chlorophyll and other pigments but lack true stems, roots, and leaves. Below are some of the identified types without being described due to limited information: i. Botryococcus spp.; Plate 3, Figures 80\&81, ii. Pseudoschizaea ozeanica; Plate 3, Figures 76\&77, iii. Oviodites parvus; Plate 3, Figures 78\&79, iv. Pediastrum spp.; Plate 3, Figure 81. 


\section{Fungi}

These consist of diverse groups of eukaryotic single-celled or multinucleate organisms that live by decomposing and absorbing the organic material in which they grow. The species identified in this study are: i. Diporotheca sp., ii. Acroconidiellina sp., iii. Ascodesmis sp. iv. Hypha, Inapertisporites sp. v. Dyadosporites sp., (Plate 4, Figures 88-99).

\section{Palynodebris elements}

Palynodebris consist of structured and structureless elements viewed from the glass slide outside the actual pollen and spores components during sporomorphs identifications. They consist of degraded organic matter, cuticles and wood fragments. For examples: i. Cuticles/plant cell, ii. Amorphous organic matter, iii. Translucent phytoclasts, iv. Opaque phytoclasts (Plates 3,4, Figure 82-87\&100104), (Plates 4\&5, Tables 4\&5).

Table 4 Fungi, Plant stomates on leaf cuticles

\begin{tabular}{|c|c|c|c|}
\hline Figure & Family name & Morphological name & References \\
\hline 88 & Fungi & Diporotheca sp. & Gelorini et al. ${ }^{8}$ \\
\hline 89 & Fungi & Acroconidiellina sp. & Ellis $^{74}$ \\
\hline 90 & Fungi & Ascodesmis sp. & Hanlin $^{76}$ \\
\hline 91 & Fungi & Dyadosporites sp. & Gelorini et al. ${ }^{8}$ \\
\hline 92 & Fungi & cf. Kretzschmaria clavus/cetrarioides & Gelorini et al. ${ }^{8}$ \\
\hline 93 & Fungi & Apiosordaria type & Gelorini et al. ${ }^{8}$ \\
\hline 94 & Fungi Hyphae & Haplographites xylophagus & Kalgutkar et al..$^{54}$ \\
\hline 95 & Fungi & Cirrenalia sp. & Kalgutkar et al. ${ }^{54}$ \\
\hline 96 & Fungi & Meliola sp. & Mibey et al. ${ }^{79}$ \\
\hline 97 & Fugi & Canalisporium pulchrum & Gelorini et al. ${ }^{8}$ \\
\hline 98 & Fungi & Cercophora sp. & Bell ${ }^{71}$ \\
\hline 99 & Fungi & Urocystic sp. & Vanky ${ }^{85}$ \\
\hline 100,101 & - & Stomates on leaf cuticles & - \\
\hline 102 & Palynodebris & Amorphous organic matter & Oboh, ${ }^{25}$ Tyson ${ }^{32}$ \\
\hline 103 & Palynodebris & Opaque phytoclasts & Oboh, ${ }^{25}$ Tyson ${ }^{32}$ \\
\hline 104 & Palynodebris & Translucent phytoclasts & Oboh, ${ }^{25}$ Tyson $^{32}$ \\
\hline
\end{tabular}

Table 5 Dinoflagellates

\begin{tabular}{llll}
\hline Figures & Dinoflagellate Cysts & Morphological name & References \\
\hline 105 & Dinoflagellate & Polysphaeridium sp. & Bujak et al. ${ }^{58}$ \\
106 & Dinoflagellate & Lingulodinium sp. & Wall, ${ }^{60}$ Wilson et al. ${ }^{89}$ \\
107 & Dinoflagellate & Tuberculodinium sp. & Rossignol, ${ }^{83}$ Wallll \\
\hline
\end{tabular}

\section{General discussions}

A high number of palynomorph components, including pteridophyte/bryophyte spores, gymnosperm pollen, angiosperm pollen, Foraminiferal Test Linings (FTLs), freshwater algae and fungal spores were recovered from the three studied gravity cores (GCs) (Map 1). Of the recovered components, literarily terrestrially derived forms (pollen and spores) constitute approximately $92 \%$ of the total palynomorph assemblages, whereas less than $2-3 \%$ are of marine origin (dinoflagellate cysts, FTLs). Freshwater algae, fungal spores and other types represent the remaining $6 \%$ of the total NPPs from the three GCs. On average, 25 families representing about 60 80 palynomorph species (excluding dinoflagellate cysts, unrecognised pollen and fungi) were identified (Plates 1-5). Plant tissue, such as cuticle, xylem-cell, stomata, insect-derived and palynodebris were also abundantly present (Plate 4). Similar family names exist as indicators of different ecosystem habitat groups but vary from species to species in each of the palaeovegetation belts identified (e.g., Polypodiaceae and Euphorbiaceae belong to more than one ecosystem habitat group) (Plates 1-5). Given that the traditional taxonomic guide aided in the compilations of palynomorphs and non-pollen palynomorph in this study, sporomorphs identified provides an atlas of palynomorphs at the species, genus and family level. Thus, in addition to other studies from the African region, this study is presenting a refined update on palynomorphs, NPPs, their phytoecology, taxonomy and biogeography of species identified through time from the Niger Delta.

In addition, the discussions here also links the species and NPPs derived from the identified specimens to their phytoecology and niches. Phytoecology which relates to the nature of the fossil record relative to the original plant niche provides a robust insight on vegetation succession across the Niger Delta. Thus, the phytoecological groupings / indicators established in this study, shows the abundance 
of species controlled by several factors such as eustasy, climate, edaphic, restricted condition, productivity trend, salinity trend etc. Given the detail descriptions of palynomorph and NPPs identified in this study, a summary of the species phytoecological indicators and relevance niches are discussed below:

\section{Mangrove and coastal swamp indicators}

These groups of pollen/spores identified in this study are found in the narrow strip of vegetation immediately adjacent to the ocean. It consists of swampy land crossed by sandy ridges. The mangrove environment is noted for developing a rich source rock accumulation (e.g. Mahakam Delta, Eastern Kalimantan - various references). It has an abundance of organic materials which are proteinaceous and fatty. These groupings consist of pollen derivatives from mangrove swamps and tidal estuaries/creek sub-environments (Table 1). The generic environment is one of a salt tolerant intertidal marsh which has a characteristic vegetative type recognised to have covered approximately $75 \%$ of tropical coastlines. Rhizophora spp. is an important component of mangrove habitats in southern America, ${ }^{62,63}$ in West Africa, ${ }^{11,39}$ across Borneo / Indonesia, ${ }^{39}$ Kenya, Oman and the eastern and northern sea-boards of Australia. Other mangrove pollen groups studied from the GCs include Apocynaceae, Euphorbiaceae, Avicenniaceae and Anacardiaceae (Plate 1).

\section{Freshwater swamp and palmae indicators}

Pollen and spores belonging to this group are associated with mixed fluvial alluvial plain and marine/tidally influenced coastal swamps, particularly in shallow water where the plants develop. ${ }^{63}$ This study observed that most species identified could be found in estuaries. This forms a transition zone between river and oceanic (marine) environments and are subject to both marine influences, such as tides, waves, the influx of saline waters, and riverine influences, such as fresh water plumes and pervasive sediment input. The inflow of both seawater and freshwater provide high levels of nutrients in both the water column and sediment, making estuaries among the most productive natural habitats in the World. Some prominent pollen found in these groups belong to these families: Hypericaceae, Clusiaceae, Malvaceae, Asteraceae and Cyperaceae (Plates 1\&2).

\section{Lowland rainforest open forest indicators}

These relative hinterland groups of pollen/spores are quite dominant in this study indicating that a good number of plant families thrive well in rainforest environments in tropical settings. ${ }^{24,63}$ Large quantities of fossil pollen (mostly angiosperms) with botanical affinities assigned to tropical rain forest plants were recovered from the three GCs. These pollen (Nymphaceae), and spores corresponding to their existing parent assemblages are listed in Table 1. Some other prominent examples among these are fern spores, Polypodiaceae, Lycopodiaceae and Sphagnaceae (Plates 1-3).

\section{Savannah and afromontane indicators}

These groups of pollen/spores identified in this study belong to tropical grasslands with a scattering of shrubs and small and large trees. Savannah environments may be linked from soil conditions, from periodic fires caused by lightning or set by humans, or from climatic influences. Savannahs as found in western and south-western Africa, develop in regions with marked wet and dry seasons, where rainfall ranges between 100 and $400 \mathrm{~mm}$ (4 and 16 in) a year 1989. The most important contributor to this group is tropical grass pollen, Poaceae, which belongs to the Poaceae family, restricted principally to more open vegetation. Morley ${ }^{39}$ in their study from the Niger Delta recorded a significant number of charred cuticles from the Cenozoic sedimentary deposits in the Niger Delta (Plate 3). Afromontane groups consist predominantly of the bisaccate pollen group belonging to the family of Podocarpaceae. Their morphology and buoyancy (saccates) allow them to be transported far and wide through both wind and water mediums (Plates 2-4).

\section{Non pollen palynomorphs (NPPs) indicators}

NPPs consist of non-pollen palynomorphs which were not grouped among the pollen taxa identified in this study. Among the types discussed, this study considered Foraminiferal Test Linings, fresh water algae and cuticles because of their environmental significance (Plates 3-5).

They consist of the following sub-groups: Foraminiferal Test Linings (FTLs): These are test materials from assumed juvenile foraminifera usually made of carbonaceous, porcelaneous and mineral from inner lining of the chambers. Brackish water algae indicators: These are sets of algae identified in this study thrive in water columns that have more salinity than fresh water, but not as much as sea water. ${ }^{39,64}$ They may result from mixing of sea water with fresh water, as in estuaries, or it may occur in fossil brackish water aquifers. Technically, brackish water contains between 0.5 and 30 grams of salt per litre - more often expressed as 0.5 to 30 parts per thousand (ppt or $\%)$. Therefore, "brackish" covers a range of salinity regimes and is not considered as being precise in its definition. ${ }^{39,64}$

Fresh water algae indicators: Refers to algae that are microscopic free-floating plants. These algae observed in this are normal and essential inhabitants of sunlit surface waters. A common form of algae in ponds is planktonic algae. Some of planktonic algae recognised from the GCs are Pediastrum spp., Pseudoschizaea ozeanica, and Ovoidites parvus belong to the freshwater green algae family Zygnemataceae (Plate 4). ${ }^{65-72}$ Fungal spore hyphae indicators: Fungi identified in this study are a varied group of generally small organisms that derive their food from living or dead organic matter. They germinate from reproductive cells called spores, which often have a thick, resistant outer coat that protects against unfavourable environmental conditions (Plate 4). ${ }^{73-81}$

\section{Conclusions and implications}

As an addendum, it is important to conclude that this study identified low occurrences of dinoflagellate cysts taxa. Possible suggestions from previous findings made it clear that the siliciclastic influx (sedimentation rate) of palaeo discharge on Niger Delta could have affected their preservation due to overburden sedimentation stress at the shallow depth. In addition, the effects of "freshwater plumes" and "tidal inundation" originating from the ocean-land boundary have been documented to provoke the hydrologic control influencing stress on their preservation in northwest Borneo, Mississippi Delta, Amazon Delta and southern New England (USA) basins. Finally, the statistical computation of the vegetation, climate and environmental dynamics aspect of this study is already published. Thus, in addition to the published articles from the region, this compendium of taxonomic and morphological descriptions update from the Niger Delta (Nigeria) is provided to facilitate the use of tropical and non-pollen palynomorphs to aid in the proper identification past plant taxa (pollen and spores), NPPs (fungi, algae, and palynodebris elements). Each of the identified sporomorph and NPPs were grouped as indicators of different phytoecology, palaeoenvironmental change (climate / sea level change) and ecological habitats to reinforce the use of pollen atlas for the reconstructions of the African Vegetation in the future. ${ }^{81-89}$ 


\section{Palynomorphs photomontage (microphotography)}

All scale bars are at $20 \mu \mathrm{m}$ except for Rhizophoraceae, which is $10 \mu \mathrm{m}$.

See taxonomy discussion section for reference depths and descriptions of some of the important taxa, which required detailed measurements.

\section{Acknowledgments}

This research study was sponsored by the Petroleum Technology Development Fund of Nigeria (PTDF). Without their funding, this research would have been difficult for me $(\mathrm{OA})$ to undertake in an overseas environment. Many thanks to Dr. Jennifer O'Keefe (Morehead State University, Kentucky, USA); Dr. Lydie Dupont (Bremen University, Germany); Carlos Jaramillo (Smithsonian Research Group, USA) and Dr. Walaa Awad (University of Wisconsin-Madison). who reviewed and significantly contributed to family affinities of the vegetation groupings and NPPs, and confirmed some of the pollen taxa. The Shell Petroleum - Geological Services team (Port Harcourt) are thanked for the provision of sample materials to assist the successful research program to end well.

\section{Conflicts of interest}

The author declares there is no conflicts of interest.

\section{References}

1. Davis MB, Faegri K. Forest tree pollen in South swedish peat bog deposits, by L. von Post (translation). Pollen et Spores. 1967;9:375-401.

2. Faegri K, Iversen J. Textbook of Pollen Analysis, 4th ed. Wiley, Chichester. 1989.

3. Roubik DW, Moreno PJE. Pollen and spores of Barro Colorado Island. 1991. p. 1-268.

4. Rull V. Middle Eocene Mangroves and Vegetation Changes in the Maracaibo Basin,Venezuela. PALAIOS. 1998;13(3):287-296.

5. Reille M. Pollen and Spores from Europe and North Africa, 2nd ed. 1999

6. Lezine AM, Cazet JP. High resolution pollen record from core KW31 Gulf of Guinea, documents the history of the lowland forests of West Equatorial Africa since 40,000 year ago. Quaternary Research. 2005;64(3):432-443

7. Riollet G. Bonnefille R. Pollen from the Amaranthacées of Lake Rodolphe (East Africa). Pollen Spores. 1976;18:67-92.

8. Gelorini V, Verbeken A, Van Geel B, et al. Modern non-pollen palynomorph (NPP) diversity in East African lake sediments. Review of Palaeobotany and Palynology. 2011;164(3-):143-173.

9. Maley J. Contributions to the study of the Chadian basin Pollen Atlas of Chad. Bulletin du Jardin botanique national de Belgique. 1970;40(1):2948.

10. Ybert JP. Pollen Atlas of Ivory Coast. 1979.

11. Germeraad JH, Hopping CA, Muller J. Palynology of Tertiary Sediments from Tropical Areas. Review of Palaeobotany and Palynology. 1968;6(34):189-348.

12. Legoux O. Some species of pollen from Nigeria. Centre for Exploration Production Elf Aquitaine. 1978;265-317.

13. Sowunmi MA. Aspects of Late Quaternary vegetational changes in West Africa. Journal of Biogeography. 1981;8(6):457-474.

14. Bankole IS, Schrank E, Osterloff P. Palynostratigraphy, palaeoclimates and palaeodepositional environments of the Miocene aged Agbada For- mation in the Niger Delta, Nigeria. Journal of African Earth Sciences. 2014;95:41-62.

15. Eduard Meine Van Zinderen Bakker. South African Pollen Grains and Spores III. Plant spores. 1953.

16. Scott L. Late quaternary fossil pollen grains from the Transvaal, South Africa. Rev Palaeobot Palynol. 1982;36(3-4):241-278.

17. White F. The vegetation of Africa: A descriptive memoir to accompany the UNESCO/AETFAT/UNSO vegetation map of Africa. Natural Resources Research. 1983;20:271-324.

18. El Ghazali GEB. A study on the pollen flora of Sudan. Rev Palaeobot Palynol. 1993;76(2-4):99-345.

19. Dupont LM, Agwu CO. Environmental control of pollen grain distribution patterns in the Gulf of Guinea and offshore NW-Africa. Geologische Rundschau. 1991;80(3):567-589.

20. Gosling W, Miller C, Livingstone DA. Atlas of the tropical West African pollen flora. Review of Palaeobotany and Palynology. 2013;199:1-135.

21. Monga, Priyanka kumar, Madhav Joshi, et al. Morphological variations and depositional processes of microforaminiferal linings in the early Tertiary sediments of northeastern and northwestern India. Palaeobotanist. 2015;64(2):129-138

22. Fletcher WJ. Holocene Landscape History of Southern Portugal. Cambridge University Press. 2005.

23. International Palynological Congress and Palaeobotany Conference, Tokyo, Japan. 2012

24. Adojoh O, Marret FD, Osterloff P, et al. Tropical palaeovegetation dynamics, environmental and climate change impact from the low latitude Coastal Offshore Margin, Niger Delta, Gulf of Guinea. Palaeoecolgy of Africa. 2017;1-38.

25. Oboh FE, Salami MB, Chapman JL. Palynological interpretation of the palaeo environments of Miocene strata of the well Igbomotoru-1, Niger Delta. Journal of Micropalaeontology. 1992;11:1-6.

26. Shell Petroleum Development Company, Nigeria. 2000.

27. Rull V. High impact palynology in petroleum geology. Applications from Venezuela (northern South America). AAPG Bulletin. 2002;86(2):279300 .

28. Punt W, Hoen PP, Blackmore S, et al. Glossary of pollen and spore terminology. Review of Palaeobotany and Palynology. 2007;143(1-2):1-81.

29. Mudie PJ, Leroy SAG, Marret F, et al. Non-pollen palynomorphs: Indicators of salinity and environmental change in the Caspian-Black Sea-Mediterranean corridor. The Geological Society of America. 2011;473:89-115.

30. Miller CS, Gosling WD. Quaternary forest associations in lowland tropical West Africa. Quaternary Science Reviews. 2014;84:7-25.

31. Adegoke OS. Foraminifera fauna of the polyhaline lagoons of the Gulf of Guinea. Journal Mining and Geology. 1975;12:1-8.

32. Tyson RV. Sedimentary Organic Matter. 1995.

33. T van der Hammen. The development of Colombian flora in geological periods. Boletin Geologico, 1954;2(1):49-106.

34. Salard Cheboldaeff M. Intertropical African palynostratigraphy from Cretaceous to late Quaternary times. Journal of African Earth Sciences. 1990;11(1-2):1-24.

35. Van der Hammen T, Wymstra TA. A palynology study on the Tertiary and Upper Cretaceous of British Guiana. Leidse Geol Meded. 1964;30(1):183-241.

36. Lorente M. Palynology and palynofacies of the Upper Tertiary in Venezuela. Dissert Botany. 1986;99:1-222. 
37. Takahashi K, Jux U. Palynology of Middle Tertiary lacustrine deposits from the Jos Plateau, Nigeria. 1989;29(2):181-367.

38. Evamy DB, Haremboure J, Kamerling P, et al. Hydrocarbon Habitat of Tertiary Niger Delta. AAPG. 1984;6:21-39.

39. Morley RJ, Richards K. Gramineae cuticles: A key indicator of Late Cenozoic climatic change in the Niger Delta. Review of Palaeobotany and Palynology. 1993;77(1-2):119-127.

40. Morley RJ. Biostratigraphic characterisation of systems tracts in Tertiary sedimentary basins. Proceedings of International Symposium on Sequence Stratigraphic in SE Asia. 1996;49-71.

41. Salard Cheboldaeff MJM, Brunet M. Tertiary Paleoflora of the Anloua Basin Adamaoua Plateau, Cambun. Revista Espanola Micropaloentol. 1992;12:131-162.

42. Regali MSP, Uesugui N, Santos AS. Palynology of Brazilian Mesocenozoic Sediments. 1975;17:177-191.

43. Salard Cheboldaeff M. On Maastrichtian and Tertiary palaeoflore of the coastal sedimentary basin of Cameroon. Pollen et Spores. 1978.

44. Salard Cheboldaeff M. Palynologie maestrichtienne et tertiaire du Cameroun. Etude qualitative et répartition verticale des principales espèces. Rev Palaeobot Palynology. 1979;28(3-4):365-388.

45. Jan du Chene RE, Salami MB. Palynology and micropaleontology of the Upper Eocene of the well Nsukwa-1, Niger Delta, Nigeria. 1978;13:5-9.

46. Van der Hammen T. Climatic periodicity and evolution of South American Maastrichtian and Tertiary floras. Boletı'n Geolo'gico. 1957;5:49-91.

47. Hoeken Klinkenberg van PMJ. Maastrichtian Paleocene and Eocene pollen and spores from Nigeria. Leidse geologische Mededelingen. 1966;38(1):37-44.

48. Niger Delta Consortium. Stratigraphic resolution on the Niger Delta. 2000 .

49. Krutzsch W. Atlas of Middle and Late Tertiary dispersed spores and pollen, as well as the microplanktonic forms of Northern Central Europe. Lieferung I. Veb Gustav Fischer Verlag Jena. 1962.

50. Krutzsch W. Atlas of Middle and Late Tertiary dispersed spores and pollen, as well as the microplanktonic forms of Northern Central Europe. Gustav Fischer Verlag Jena. 1967.

51. Frederiksen NO. Middle Eocene palynomorphs from San Diego, California; Part I: Introduction, spores and gymnosperm pollen. 1983.

52. Sah SCD. Palynology of an Upper Neogene profile from Rusizi Valley (Burundi). Koninklijk Museum voor Midden-Afrika Tervuren, Belgie Annalen Reeks in $8^{\circ}$ Geologische Wetenschappen. 1967;57:173.

53. Stuchlik L. Atlas of pollen and spores of the Polish Neogene. 2001.

54. Kalgutkar J. AASP Contribution Series. 2000.

55. Kar RK. Occurrence of Acrostichum spores from the Langpar Formation Early Palaeocene of Meghala, India. Geophytology. 1992;22:33-36.

56. Nagy E. Sporomorphs of the Neogene in Hungary. Geologica Hungarica -Series Palaeontologica. Fasciculus. 1985;47:471.

57. Sullivan HJ, Marshall AE. Visean spores from Scotland. Micropaleontology. 1966;12(3):265-285.

58. Bujak JP, Downie C, Eaton GL, et al. Dinoflagellate cysts and acritarchs from the Eocene of southern England. Special Papers in Palaeontology. 1980;24:1-100.

59. Jaramillo CA, Dilcher DL. Middle Paleogene palynology of central Colombia, South America: A study of pollen and spores from tropical latitudes. Palaeontographica. 2001;6:87-213.
60. Wall D. Fossil microplankton in deep-sea cores from the Caribbean Sea. Palaeontology. 1967;10(1):95-123.

61. A de Vernal. Marine palynology and its use for studying near shore environments. From Deep-sea to Coastal Zones: Methods and Techniques for studying paleoenvironments. IOP Conf Series: Earth and Environmental Science. 2009;5:1-13.

62. Gifford RM. Whole plant respiration and photosynthesis of wheat under increased $\mathrm{CO}_{2}$ concentration and temperature: long-term vs. short-term distinctions for modelling. Global Change Biology. 1995;1(6):385-396.

63. Rull V. A quantitative palynological record from the Early Miocene of western Venezuela, with emphasis on mangroves. Palynology. 2010;25(1):109-126.

64. Batten DJ, Lister JK. Evidence of freshwater dinoflagellates and other algae in the English Wealden (Early Cretaceous). Cretaceous Research. 1988;9(2):171-179.

65. Thiergart F, Frantz U. Some spores and pollen grains from Tertiary brown coal deposit in Kashir. Palaeobotany. 1962;10:84-86.

66. Sowunmi MA. Pollen morphology in the Palmae with special reference to trends in aperture development. Review of Palaeobotany and Palynology. 1968;7(1):45-53.

67. Smith AR, Pryer KM, Schuettpelz E, et al. A classification for extant ferns. Taxon. 2006;55(3):705-731.

68. Simmons MD, Bidgood MD, Brenac P, et al. Microfossil assemblages as proxies for precise palaeoenvironmental determination, an example from Miocene sediments of North-West Borneo. Geological Society. $1999 ; 152: 219-241$

69. Shell. Location of map of Niger Delta and core positions. 2011.

70. Adekanmbi OH, Ogundipe OT. Pollen grains of Lagos lagoon swamp and hinterland vegetation. International Journal of Botany. 2009;5(4):270 278.

71. Bell A. Dung Fungi. An illustrated guide to the Coprophilous fungi in New Zealand. Journal New Zealand Journal of Botany. 1983;22(4):593.

72. Chase MW, Salamin N, Wilkinson M. Land plants and DNA barcodes: short-term and long-term goals. Philos Trans $R$ Soc Lond B Biol Sci. 2005;360(1462):1889-1895.

73. Delcourt A, Sprumont G. Spores and pollen grains from Wealdien $d u$ Hainaut. Mémore Society Belgium Géologis. 1955;5:1-73.

74. Ellis MB. More dematiaceous Hyphomycetes.Commonwealth Mycological Institute. Kew, Surrey. 1976.

75. Erdtman G. Pollen morphology and plant taxonomy (An introduction to palynology 1) Angiosperms, Almqvist and Wiskell, Stockholm, Chronica Botanica Co. Waltham Mass. 1952

76. Hanlin RT. Illustrated genera of Ascomycetes. 1990

77. González Guzmán AE. A Palynological study on the Upper Los Cuervos and Mirador Formations (Lower and Middle Eocene; Tibú area, Colombia). EJ Brill. 1967.

78. Goremykin VV, Hellwig FH. Evidence for the most basal split in land plants dividing bryophyte and tracheophyte lineages. Plant Systematics and Evolution. 2005;254(1-2):93-103.

79. Mibey RK, Kokwaro JO. Two new species of Meliola from Kenya. Fun gal Diversity. 1999;2:153-157.

80. Pospelova V, Gail LC, Henry AW. Environmental factors influencing the spatial distribution of dinoflagellate cyst assemblages in shallow lagoons of southern New England, USA. Review of Palaeobotany and Palynology. $2004 ; 128(1-2): 7-34$. 
81. Potonié R. Synopsis of the genera Sporae dispersae II part: Sporites. 1960;39(31):1-114.

82. Prager A, Barthelmes A, Theuerkauf M, et al. Non-pollen palynomorphs from modern Alder carrs and their potential for interpreting microfossil data from peat. Review of Palaeobotany and Palynology. 2006;141(12):7-31.

83. Rossignol M. Analyse pollinique de sediments marins Quaternaries en Israel. II Sediments Pleistocenes. Pollen et spores. 1962;4:121-148.

84. Saad SJ, Ghazaly G. Palynological evidence in Nubia Sandstone from Khnaga oasis. Pollen et Spores. 1976;18:407-470.
85. Vánky K. European Smut Fungi. Gustav Fischer Verlag. Stuttgart, Jena, New York. 1996

86. University of Arizona, Heberium collection. 2011.

87. T van der Hammen, García de Mutis C. The Paleocene pollen flora of Colombia. Leidse Geol Meded. 1965;35(1):105-114.

88. AA Balkema. Amsterdam/Cape Town.

89. Wilson GJ, Clowes CD. Arachnodinium, a new dinoflagellate genus from the Lower Tertiary of Antarctica. Palynology. 1982;6:97-103. 